慶應義塾大学学術情報リポジトリ

Keio Associated Repository of Academic resouces

\begin{tabular}{|c|l|}
\hline Title & $\begin{array}{l}\text { Energy resolution of liquid scintillator for a-particles and internal conversion electrons at lower } \\
\text { temperatures }\end{array}$ \\
\hline Sub Title & \multicolumn{1}{|c|}{} \\
\hline Author & $\begin{array}{l}\text { 本間, 義夫(Honma, Yoshio) } \\
\text { 村瀬, 裕子(Murase, Yuko) }\end{array}$ \\
\hline Publisher & 共立薬科大学 \\
\hline Publication year & 1987 \\
\hline Jtitle & $\begin{array}{l}\text { 共立薬科大学研究年報 (The annual report of the Kyoritsu College of } \\
\text { Pharmacy). No.32 (1987.) ,p.80-81 }\end{array}$ \\
\hline JaLC DOI & \\
\hline Abstract & \\
\hline Notes & 抄録 \\
\hline Genre & Technical Report \\
\hline URL & https://koara.lib.keio.ac.jp/xoonips/modules/xoonips/detail.php?koara_id=AN00062898-0000003 \\
2-0080
\end{tabular}

慶應義塾大学学術情報リポジトリ(KOARA)に掲載されているコンテンツの著作権は、それぞれの著作者、学会または出版社/発行者に帰属し、その権利は著作権法によって 保護されています。引用にあたっては、著作権法を遵守してご利用ください。

The copyrights of content available on the KeiO Associated Repository of Academic resources (KOARA) belong to the respective authors, academic societies, or publishers/issuers, and these rights are protected by the Japanese Copyright Act. When quoting the content, please follow the Japanese copyright act. 
No. 32 (1987)

\title{
Energy Resolution of Liquid Scintillator for $\alpha$-Particles and Internal Conversion Electrons at Lower Temperatures*
}

\author{
Yoshio Homma and Yuko Murase \\ 本間義夫，村瀬裕子
}

The use of liquid scintillation methods for the energy analysis of an $\alpha$-spectrum has been demonstrated by several investigators. Horrocks reported a $5.8 \%$ energy spread for $\alpha$-particles energies between 4 and $7 \mathrm{Mev}$ using a specially constructed single-phototube instrument. With the experimental means available, at ordinary temperature, there seems to be little hope to improve the resolution of liquid scintillation systems significantly beyond the limit mentioned above.

However, in the course of the spectral studies described in the preceding papers, we have found that the pulse-height for $\alpha$ and $\beta$-particles and for internal conversion electrons in several kinds of organic scintillator solutions increases markedly with decreasing temperature: The energy resolution of $\alpha$-particles from ${ }^{241} \mathrm{Am},{ }^{222} \mathrm{Rn},{ }^{218} \mathrm{Po}$ and ${ }^{214} \mathrm{Po}$ and internal conversion electrons from ${ }^{131 \mathrm{~m}} \mathrm{Xe}$ with a liquid scintillation system has shown to give better energy resolutions with decreasing temperature.

In early experiments that may be compared with the present study, most investigators have reported line width of $24-50 \%$ for approximately $5 \mathrm{MeV} \alpha$-particles, which are much poorer than the present values listed: The energy resolution for $\alpha$-particles measured even at $13^{\circ} \mathrm{C}$ is $13.7 \%$ for $5.48 \mathrm{MeV}$ which is the average $\alpha$-particle energy of ${ }^{241} \mathrm{Am}$, $10.8 \%$ for $7.69 \mathrm{MeV}\left({ }^{214} \mathrm{Po}\right)$. Furthermore, the energy resolutions for these $\alpha$-particles are much higher at lower temperatures. It seems that the reported poorer results could be due, in part, to quenching effects, because aqueous solutions of the $\alpha$-emitter were used in most early reports.

The experiment on the energy resolution for electrons has been done by Flynn et al. Based on the pulse-height spectra measured by them, we can estimate graphically the energy resolution for $0.184 \mathrm{MeV}$ internal conversion electrons from ${ }^{114 \mathrm{~m}} \mathrm{In}$ at $33.1 \%$ and for $0.379 \mathrm{MeV}$ ( ${ }^{113 \mathrm{~m}} \mathrm{In}$ ) at $26.2 \%$. Whereas, in the present study, the energy resolution obtained for $0.164 \mathrm{MeV}$ electrons is estimated $44.3 \%$ at $13^{\circ} \mathrm{C}$ and $30.0 \%$ at $-65^{\circ} \mathrm{C}$. The difference between the value from the present study at $13^{\circ} \mathrm{C}$ and the reported value could be reasonably explained on the basis of the fact that a specially constructed singlephototube has been used in the early study. It is noteworthy, however, the results obtained especially at lower temperatures are comparable to those by Flynn et al.

In the present study all these factors, except the temperature of the sample, are kept

* 本報告はJ. Radioanal. Nucl. Chem. Letters, 119(5)，355-365 (1987) 飞発表. 
the same, thus, the difference in the energy resolution between at ordinary temperature and at lower temperatures is attributed to the temperature dependence of pulse-height distributions both for $\alpha$-particles and internal conversion electrons. As has been previously reported, the increase in energy transfer between solvent molecules, and hence, in light output of liquid scintillator occur at lower temperatures. Therefore, it is concluded that the improvement in energy resolution observed at lower temperatures is attributed to the increase in light output upon lowering the temperature from $13^{\circ} \mathrm{C}$ to $-65^{\circ} \mathrm{C}$, because the energy resolution is inversely proportional to the square root of the number of light quanta produced per particle emitted. 